\title{
Development of self-sufficiency village for seed provision of superior variety in Majalengka Regency
}

\author{
Irma Noviana*, and Yati Haryati \\ West Java Assessment Institute of Agricultural Technology, Lembang, Indonesia
}

\begin{abstract}
Farmer group-based seed production can support the provision of quality seed in areas according to consumer preferences. The purpose of the study was to determine the role of the Seed Self-sufficiency Village (SSV) in providing and accelerating the adoption of new high-yielding varieties of rice. This study used primary data from the assistance of the SSV Field School Model, which was carried out in the Gangsa I Farmers Group, Jatitengah Village, Jatitujuh Subdistrict, Majalengka Regency, West Java. Data on seed production by farmer group-based seed production obtained during 2016-2019 included data on the development of the number of breeders, production areas, production capacity, number of seed marketing partners and consumer preferences for new varieties produced. The data and information obtained were describe descriptively, while the data on consumer preferences for varieties were analyzed using the Friedman test. The results showed that the development of SSV in Majalengka in 20162019 showed a remarkable achievement based on the development of seed production businesses, consumer preferences, seed marketing partnership, and seed distribution parameters. The SSV supported provision of quality seeds of new superior varieties in areas according to consumer preferences. It can support accelerating the adoption of high-yielding varieties of rice.
\end{abstract}

\section{Introduction}

In supporting seed development at the community level, the government has launched a seed industry with government policies in the rice seed. The Ministry of Agriculture carries out several activities in terms of 1) Reorganizing the national seed/nursery institutions starting from the central to regional levels; 2) Protect, maintain and utilize national genetic resources for the development of superior local varieties; 3) Strengthening plant seed breeders and supervisors; 4) Empower local-based seed breeders and producers; 5) Increase the role of the private sector in developing the seed/nursery industry; and 6) Building the seed industry to support: (a) Independence of the national seed industry, which includes self-sufficiency in seed production and variety industry; (b) Independent area-based seed supply; (c) Community-based seed industry; (d) Seed-based research [1].

* Corresponding author: irma.bptpjabar@gmail.com 
To meet the need of rice seed, breeders and seed industries in the regions need to be encouraged to contribute to the provision of quality seeds by taking in to account the preferences of farmers and consumers in the local area. The development of the Seed SelfSufficiency Village (SSV) is a solution for farmers to gets superior seeds on time [2].

As an effort to ensure the sustainability of theseed self-sufficiency villages, itisnecessary to growseed breeders as one of the businesses managed by farmer groups as seedproducing institutions thatproducequalityseeds.

Empowerment of farmers towards seed-self-sufficiency villages needs to be done through field schools by empowering aspects of management, capital, and market linkages [3]. Sustainable independenceis one aspect that is the main focus. It isrealized if a sustainable system can be built between breeders as seed producers and farmers' preferences as endusers.

Seed breeders, both individuals, and groups, have an essential role in the seed industry, especially in disseminating high-yielding varieties produced by research institutions and produced by seed producers [4]. A Good breeder performance can encourage the availability of superior seeds in the local area, or even between regions, to meet the exact seed needs (type/variety, place, quality, time, quantity, and price) [5].

In increasing the capacity of rice seed breeders, a strategy is needed to carry out an empowerment program for seed breeder farmers through optimizing the role of farmer groups. Seed breeding activities will continue if they maximize the role of farmer groups in creating a seed market. The motivation of members to carry out seed breeding is fundamental [6].

The ideal seed system in supporting the use of qualityseeds at the farmerlevel can bedone by developing a community-basedseed system, through increasing the capacity of breeders, strengthening farmer group institutions, and providing source seed institutions to produce source seeds. Seed producers or seed breeders, or farmer groups that carry out seed breeding are an institutional unit that plays a vitalrole in providing quality seeds [7].

The adoption of new superior rice varieties in the field is still low because farmers' access to seeds of new rice superior varieties is still limited, and the introduction of farmers to varieties is still low. Through the development of farmer group-based seedling, it is hoped that it will support the availability of new superior varieties of seeds and increase their adoption by farmers

Majalengka regency is one of the centers of rice production in West Java with an area of 50.035 ha [8], The need of seed of this area is $1.250,875$ tons, assuming the seed requirement per hectare is $25 \mathrm{~kg}$. Thus, to meet the need for quality seeds, it is necessary to make efforts to grow seed breeders that are able to produce seeds according to regional needs and preferences.

In addition, Majalengka has rice seed breeders who are members of the Gangsa I farmer group in Jatitujuh District, which is very responsive to new varieties. Thus, the development of farmer group-based seed breeding has the potential to support the dissemination and adoption of new varieties of rice in accordance with regional preferences.

The purpose of the study was to determine the role of the Seed Self-Sufficiency Village in providing and accelerating the adoption of new high-yielding varieties of rice.

\section{Methodology}

This study used data from the Food Sovereignty Field School Model Supporting Integrated Food Self-Sufficiency in the Independent Village of Rice Seeds of the West Java Assessment Institute for Agriculture Technology in the Gangsa I Farmer Group Jatitengah Village, Jatitujuh District, Majalengka Regency, West Java in 2016-2019. Development of farmer 
group-based seed breeders based on 1) product marketing orientation based on preference, (2) establishing partnerships, and (3) business sustainability.

\subsection{The development of farmer group-based seed production businesses}

The development of farmer group-based seed production was known through the addition of the number of breeding partners were involved in seed production, the area of production land, and the capacity of the seed produced. To find out information about the development of seed raising business in the Gangsa I farmer group, interviews were conducted with farmers using questionaires and based on data of seed production activities from 2016-2019.

\subsection{Preference for new superior varieties of rice}

Preference for new superior varieties was measured to determine the level of consumer preference for plant performance by survey method using a questionnaire. The preference test was carried out to determine farmers' acceptanceof new superior varieties developed using a questionnaire tool to 20 respondents.

Respondent's preference for new varieties was seen from the assessment given with a range of $1-5$ (very dislike $=1$, dislike $=2$, middle $=3$, like $=4$, very like $=5$ ). The aspects measured include the agronomic character of crops in the field, production, grain shape and size, and rice taste. Preference data were analyzed using the Friedman Test to determine differences in respondents' preferences for varieties. If there is a different assessment between varieties, then the test is continued with the ranking method to find out which variety is most favored by consumers.

\subsection{Seed marketing partnership}

In line with the increase in seed production capacity, it is necessary to develop a partnership network in seed marketing. Partnership in marketing of seeds based on cooperation agreements with farmer shops, farmer groups, farmers and state-owned companies (PT. Pertani and PT Sang Hyang Seri). Data on the development of seed marketing partners was obtained from interviews with the Gangsa I farmer group based on the number of seed marketing cooperation partners since 2016-2019.

\subsection{Distribution of new superior varieties of rice}

The distribution of seed produced by Gangsa I farmer group was conducted through marketing cooperation partners both inside and outside the Majalengka area.

Seed distribution data were obtained from demand data by marketing partners from 20162019. Data and information including the development of the number of breeders, production area (ha) seed production capacity (tons), number of marketing partners and seed distribution since 2016-2019 were then described descriptively. 


\section{Results and discussions}

\subsection{The development of farmer group-basedseed production businesses}

Seed business activities in farmer groups were developed in farmers/seed breeders to produce seeds of varieties according to farmers' preferences in the Seed Self-sufficiency Village (SSV) area and based on consumer preferences outside the region.

Success in seed production was also influenced by area and land tenure [9]. The more extensive the land and the control, the smoother and higher production activity [10]. The development of the number of breeders, land area, and production capacity of the seed selfsufficiency village continues to grow. Collaboration with breeders outside of the Seed selfsufficiency village as cooperation partners is carried out in increasing production capacity to meet seed needs according to consumer demand and preferences.

Seed production capacity by farmer groups can be developed by providing a stimulus to joint group efforts [11]. Furthermore, according to [12], that the factors that influence the involvement of farmers in partnerships are land area, experience, perception, age, education level, and family responsibilities.

Seed breeders as producer partners are very necessary, especially if producers do not have sufficient capital to rent land and laborcosts in the fields. Some breeders relied on their land or rent because the cost of renting the land was cheap, and they had sufficient capital [13].

The development of the number of breeders, production area, and production capacity from 2016-2019 is presented in Figure 1.

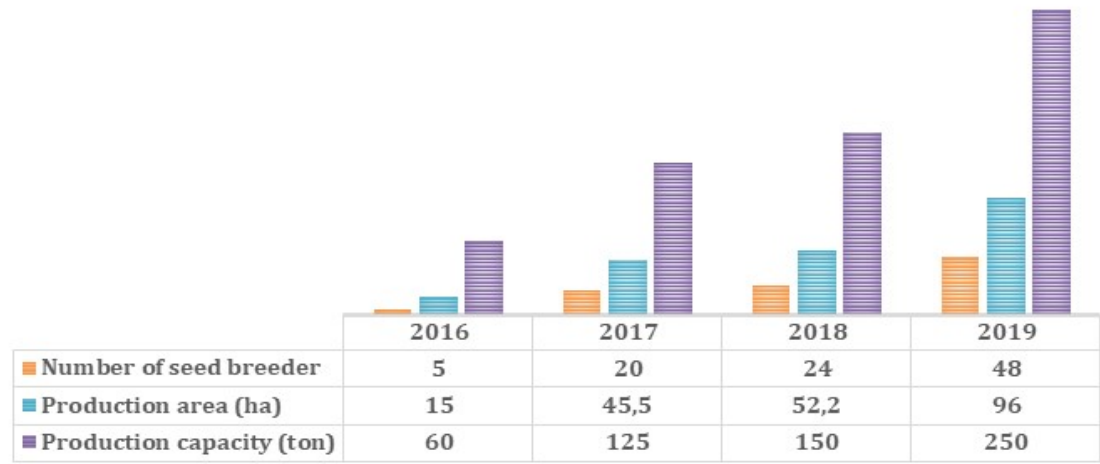

Fig. 1. Development of the number of breeders, area of seed production, and seed production capacity of the Gangsa I Farmer Group, Jatitengah Village, JatiTujuh District, Majalengka Regency, 2016-2019

The sustainability of seed breeding by farmer groups can not be carried out individually but must becarried out in groups, because it is related to capital, labor, land area, and rules that require groups. Mean while, to increase the capacity of seed breeders, it is necessary to optimize the role of seed breeder farmer groups as a forum for learning, cooperation, seed production units, and product marketing units [14].

\subsection{Preference for new superior varieties of rice}

Demand for seeds that consumers like or are interested in needs to be studied/assessed before production is carried out, so that the number of seeds to be produced can be estimated to prevent shortages or excess supply of seeds [15]. 
Preference test was carried out to find out consumer interest in the variety to be produced. This test was conducted at the previous season's rice cropping on new superior varieties of rice that would be made in the next season. This preference test was very important for seed producers as a business planning effort to determine consumer interest in a variety and its marketing potential.

In this study, the preference test data displayed were the results of tests on the second season of rice planting in 2019, as a reference for planning seed production in 2020 (Table $1)$.

Table 1. Farmers' preferences on rice crops performance in 2019

\begin{tabular}{|l|c|c|c|c|c|c|c|c|}
\hline \multicolumn{1}{|c|}{ Variety } & Height & $\begin{array}{c}\text { Number } \\
\text { of tillers }\end{array}$ & $\begin{array}{c}\text { Panicle } \\
\text { length }\end{array}$ & $\begin{array}{c}\text { Harvest } \\
\text { age }\end{array}$ & $\begin{array}{c}\text { Pest \& } \\
\text { diseases } \\
\text { resistance }\end{array}$ & $\begin{array}{c}\text { Grain } \\
\text { shape }\end{array}$ & Production & $\begin{array}{c}\text { Plant } \\
\text { shape }\end{array}$ \\
\hline \multicolumn{7}{|c|}{ Mean Rank } \\
\hline Pajajaran & 3.73 & 3.32 & 3.09 & 3.36 & 3.49 & 3.21 & 3.48 & 3.16 \\
\hline Munawacita & 2.82 & 3.12 & 3.38 & 3.39 & 2.98 & 3.18 & 2.78 & 2.82 \\
\hline Cakrabuana & 3.70 & 3.80 & 3.82 & $\mathbf{3 . 6 8}$ & $\mathbf{4 . 0 1}$ & 3.61 & 3.83 & 3.79 \\
\hline Siliwangi & 3.51 & 3.48 & 3.44 & 3.52 & 3.64 & 3.64 & 3.59 & 3.74 \\
\hline Rindang 2 & 2.98 & 3.31 & 3.40 & $\mathbf{3 . 6 8}$ & 3.62 & 3.63 & 3.43 & $\mathbf{3 . 8 2}$ \\
\hline Inpari 42 & $\mathbf{4 . 2 6}$ & $\mathbf{3 . 9 8}$ & $\mathbf{3 . 8 7}$ & 3.36 & 3.27 & $\mathbf{3 . 7 3}$ & $\mathbf{3 . 9 0}$ & 3.67 \\
\hline \multicolumn{7}{|c|}{ Friedman Test } \\
\hline N & 47 & 47 & 47 & 47 & 47 & 47 & 47 & 47 \\
\hline Chi-Square & 34.98 & 14.50 & 10.82 & 3.24 & 16.60 & 8.80 & 20.30 & 21.35 \\
\hline Df & 5 & 5 & 5 & 5 & 5 & 5 & 5 & 5 \\
\hline Asymp. Sig. & 0.000 & 0.013 & 0.055 & 0.662 & 0.005 & 0.117 & 0.001 & 0.001 \\
\hline
\end{tabular}

Remark: Asym. Sig. $<0.05$ means that the respondents' assessment of several varieties is significantly different.

Based on the Friedman Test, it was found that the respondent's preferences for the performance characteristics of the new superior varieties tested showed significant differences in plant height, number of tillers, resistance to pests and diseases, yield, and plant shape parameters. On the variables of plant height, the number of tillers, panicle length, grain shape, and production yield, Inpari 42 was the most preferred variety by farmers. In the term of parameters so the harvest age and resistance to pests and diseases, Cakrabuana is the variety most favored by farmers because of its favorite rice taste. The results of preference testing on plant performance showed that Inpari 42 was preferred over other varieties. The varieties that farmers potentially favor in the next growing season are the Inpari 42 and Cakrabuana rice varieties so that the two varieties have the opportunity to be further developed.

Farmer's preferences for a variety to bedevelopedwerestronglyinfluenced by the taste of riceaccording to local tastes. For the West Java province, the preferred texture of rice is fluffier, so that in addition to the potential for high productivity and resistance to pest and disease attacks, the texture of rice from the varieties to be produced is also an important thing that rice seed breeders/producers need to pay attention to.

The study of new high yielding varieties of rice in development areas involving the participation of farmers is believed to accelerate the adoption and spread of varieties. This provides an opportunity for farmers to play an active role in choosing the varieties to be developed according to their preferences. The use of new high yielding varieties of lowland rice cultivated with an integrated crop management approach contributes significantly to increasing dry grain yields compared to conventional cultivation [16].

The development of the number of varieties produced by SSV farmer groups in the District of Jatitujuh, Majalengka Regency from 2016 to 2019 is presented in Table 2. 
Table 2. Development of the number and vareties produced by SSV farmer groups in Jatitujuh

District, Majalengka Regency during 2016-2019

\begin{tabular}{|l|l|l|l|l|}
\hline \multicolumn{1}{|c|}{ Year } & $\mathbf{2 0 1 6}$ & $\mathbf{2 0 1 7}$ & \multicolumn{1}{c|}{$\mathbf{2 0 1 8}$} & \multicolumn{1}{c|}{$\mathbf{2 0 1 9}$} \\
\hline Number of Variety & 2 & 1 & \multicolumn{1}{c|}{6} \\
\hline Variety & Inpari 31 & Inpari 32 & Inpari 24 & Inpari 32 \\
& Inpari 32 & & Inpari 32 & Inpari 39 \\
& & & Inpari 33 & Inpari 42 \\
& & & Inpari 39 & Inpari 43 Padjaradjaran \\
& & & Inpari 42 & Munawacita Cakrabuana \\
& & & Inpari 43 & Rindang 2 \\
\hline
\end{tabular}

Table 2 showed that Inpari 32, which had been produced since 2016, received a very good response from farmers in terms of the aspect of high production potential, resistance to pests and diseases, and the preferred taste of rice. Therefore, the demand for and adoption of this variety is always high every year.

\subsection{Seed marketing partnership}

To support the sustainability of rice seed breeding, it is necessary to partner with business actors in marketing seeds. The development of partnerships with cooperation partners from 2016 - 2019 continued to increase a long with the increase in rice seed production capacity (Figure 2). The partnership development was carried out as an effort to market rice seeds in accordance with the amount of seed production produced by farmer groups as rice seed breeding institutions.

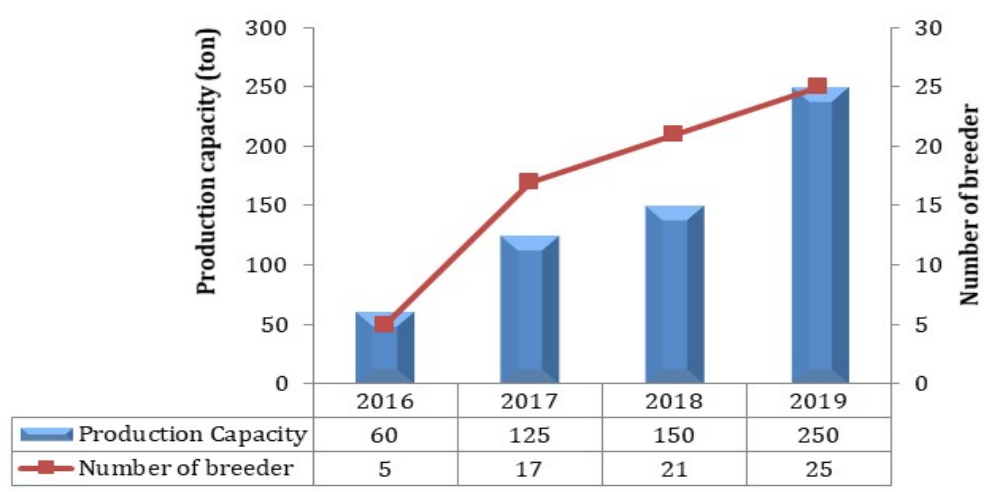

Fig. 2. Development of seed production volume and number of partners in seed marketing cooperation in 2016-2019.

Partnerships are carried out with farmer groups, farm shops, relevant agencies in the seed assistance program, and State-Owned Enterprises in the seed business sector such as with PT. Sanghyang Seri and PT. Pertani. Farm shops generally come from the Majalengka area, so that with the increase in the seed marketing network, the spread of new superior varieties of rice in Majalengka is increasing.

\subsection{Distribution of new superior varieties of rice}

Along with the development of seed production capacity by the seed-self-sufficiency villages farmer groups, also followed by the expansion of seed distribution from 2016-2019 (Figure 
3). In 2016, the distribution of rice seeds produced more dominant for the District of Jatitujuh and some districts in Majalengka (97\%). In 2017, the distribution of rice seeds began to expand out of Majalengka Regency by $20 \%$, namely to Cirebon, Indramayu and PemalangRegencies, Central Java.In 2018, the proportion of seed distribution for the Majalengka Regency area was more dominant (97.3\%) due to the collaboration with the Majalengka Regency Government for the seed assistance program.

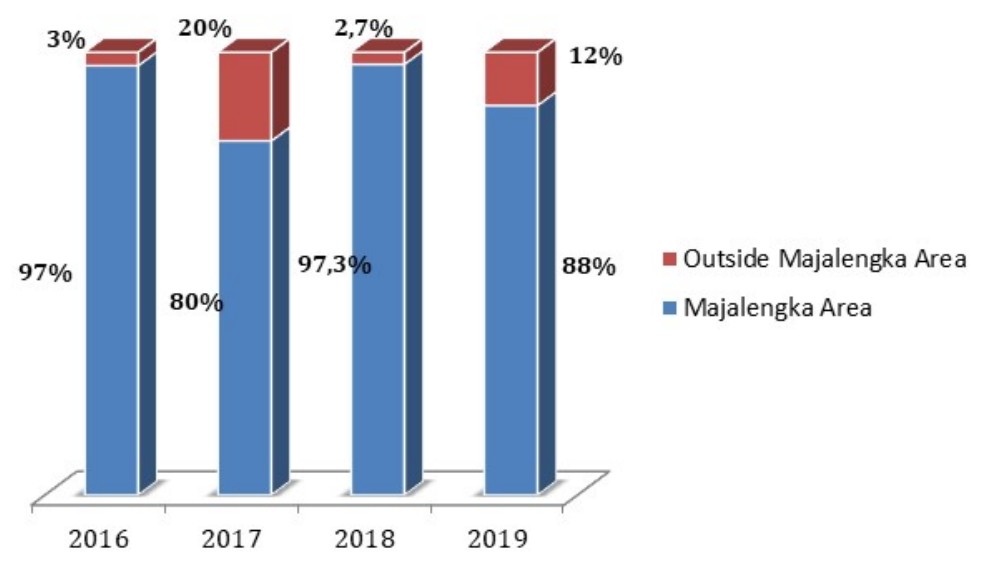

Fig. 3. The development of the area distribution of seeds by farmer's groups' independent villages seed rice in the year 2016-2019

The study indicated that the acceleration of rice high-yielding varieties is dominantly determined by the needs of farmers on their preferenced rice variety.Often new superior rice varieties do not develop because they cannot respond to the challenges in the location (biotic and abiotic threats) and are not underfarmer's preferences. For this reason, the development of new superior varieties must consider the interests and needs of farmers in the targeted development areas.

\section{Conclusion}

The development of Seed Self-suffiency Villages (SSV) in Majalengka Regency in 20162019 showed a remarkable achievement based on the development of seed production businesses, consumer preferences, seed marketing partnership, and seed distribution parameters. Seed self-sufficiency villages supported by providing quality seeds of new superior varieties in the areas according to consumer preferences. Provision of seeds of new superior rice varieties based on farmer groups through the SSV can support an accelerating for adoption of high-yielding varieties of rice.

\section{References}

1. Kementerian Pertanian Republik Indonesia,Rencana strategis Kementerian Pertanian tahun 2010-2014, Jakarta (ID), Kementerian Pertanian (2010)

2. H. Tuanaya, J. Marcus, Pattinama, AM. Sahusilawane, AGRILAN, 7, 1 (2019)

3. PS. Setimela, P. Kosina. Strategies for Strengthening and Scaling up Community-based Seed Production. Mexico, D.F.: CIMMYT (2006)

4. A. Saleh, R. Putra, N. Purnaningsih, N. Jurnal Komunikasi Pembangunan, 14, 1 (2016) 
5. V. Darwis, Sinergy of Seed Self-Reliance-Village and Seed Self-Reliance Region Model Towards Seed Self-Sufficiency, Analisis Kebijakan Pertanian, 16, 1 (2018) DOI: http://dx.doi.org/10.21082/akp.v16n1.

6. I. Imron, MS. Soeaidy, H.Ribawanto, JurnalAdministrasiPublik, 2, 3 (2014)

7. Soekartawi, Agroindustri dalam Perspektif Sosial Ekonomi. Jakarta, Raja GrafindoPersada (2005)

8. [BPS] Badan Pusat Statistik. Jawa Barat dalam Angka. 2018

9. ME. Wulanjari, C. Setiani, Pemberdayaan Gapoktan Berkah Melalui Program Desa Mandiri Benih dalam Prosiding Seminar Nasional dalam Rangka Dies Natalis UNS Ke 42, 12-13 Apri 2018, Surakarta (2018)

10. Sudarto, W.Hipi, H. Windiyani, Penelitian Pertanian Tanaman Pangan, 2, 2 (2018).

11. R. Heryanto, Syamsuddin, H. Muhammad, Agros 16, 1 (2014).

12. BPK. Dewi, B. Setiawan, R.Isaskar. Jurnal Habitat. 22, 2 (2011)

13. B. Sayaka, Hermanto, M.Rachmat, V. Darwis, FBM. Dabukke, S. Suharyono, K. Kariyasa, Penguatan kelembagaan penangkar benih untuk mendukung kemandirian benih padi dan kedelai. Laporan Penelitian, Bogor (ID): Pusat Sosial Ekonomi dan Kebijakan Pertanian, Badan Penelitian dan Pengembangan Pertanian (2015)

14. R. Putra, A. Saleh, N. Purnaningsih, Strategi Meningkatkan Kapasitas Penangkar Benih Padi Sawah dengan Optimalisasi Peran Kelompok Tani di Kabupaten Lampung Timur, dalam Prosiding Seminar Nasional Agroinovasi Spesifik Lokasi untuk Ketahanan Pangan Pada Era Masyarakat Ekonomi ASEAN, 19-20 Oktober 2016, Bandar Lampung, Indonesia (2017).

15. B. Sayaka, D. Hidayat. Jurnal Analisis Kebijakan Pertanian, 13, 2 (2015).

16. 1. C. Setyani, M. Wulanjari, T. Prasetyo. Jurnal Riset Agribisnis dan Peternakan, 3, 2 (2018). 